\title{
VÁLLALATI ÖNKÉNTESSÉG A GYAKORLATBAN
}

\author{
MOLNÁR KLÁRA ${ }^{1}-$ VIDA VIVIEN ${ }^{2}$
}

DOI: https://doi.org/10.53585/OnkSzem.2021.4.76-93

\section{Absztrakt}

Az Effekteam Egyesület kutatásiból kiderül, hogy az elmúlt 10 évben az önkéntesség fokozatosan teret nyert a nagyvállalatok társadalmi felelősségvállalási gyakorlatában. Jelen tanulmányban három nagyvállalattal - a dm Magyarország Kft., az E.ON Hungária Zrt. és az OTP Bank Nyrt. - készült interjút dolgozunk fel. Az elemzés áttekintést kíván nyújtani a hazai piacon múködő három vállalat elmúlt 10 éves önkéntes gyakorlatának változásairól, fejlődéséről. A tanulmány keretében részletesen megvizsgáljuk, milyen kereteket biztosítottak a vállalatok az önkéntes aktivitásoknak, milyen önkétes programok születtek, valamint azt, hogyan valósítják meg a különféle típusú önkéntes kezdeményezéseket ezen cégek. Az esettanulmány végére jól körvonalazódik az a hipotézisünk, miszerint a vizsgált vállalatok társadalmi felelősségvállalási stratégiájában, gyakorlatában egyre nagyobb hangsúlyt kapnak az önkéntes kezdeményezések.

Kulcsszavak: CSR, társadalmi felelősségvállalás, felelős vállalatok, vállalati önkéntesség

\section{Corporate volunteering in practice}

\section{Klára Molnár - Vivien Vida}

\section{Abstract}

According to the research projects of Effekteam Association, it is clear that volunteering has gained ground in the practice of corporate social responsibility gradually in the last 10 years. In the present study, interviews with three large companies (dm Magyarország Kft., E.ON Hungária Zrt. and OTP Bank Nyrt.) are discussed. The analysis aims to provide an overview of the changes and evolution in the practice of volunteering of the three companies operating in the domestic market over the last 10 years. The study will examine in detail the frameworks provided by the companies for volunteering activities, the types of volunteer programs and the details of how these companies have executed different types of volunteering initiatives. By the end of the study, our hypothesis that voluntary initiatives are becoming increasingly important in the CSR strategies and practices of the companies studied is well outlined.

Keywords: CSR - corporate social responsibility, responsible companies, corporate volunteering

\footnotetext{
${ }^{1}$ Molnár Klára (univ. doc. jur), jogász, az Effekteam Egyesület igazgatója, szakmai vezetöje

${ }^{2}$ Vida Vivien, germanisztika szakos bölcsész, operatív asszisztens, Effekteam Egyesület
} 


\section{BEVEZETÉS}

Egy profitorientált vállalat nem titkolt szándéka az, hogy gazdasági teljesítménye folyamatosan kimagasló legyen. Ennek a törekvésnek azonban összhangban kell lennie többek között a munkavállalók érdekeivel és a társadalom szükségleteivel is. A vállalat, a munkavállalók és a társadalom közös, értékteremtő metszetének egyik kiemelt terepe a vállalati önkéntesség.

Jelen esettanulmányban átfogó betekintést kívánunk nyújtani három Magyarországon múködő nagyvállalat - a dm Magyarország Kft., az E.ON Hungária Zrt. és az OTP Bank Nyrt. elmúlt 10 éves önkéntes gyakorlatába. Az interjúk a cégek vállalati önkéntességért felelős képviselőivel készültek 2021 októberében. A tanulmány keretében a következő kérdéseket vizsgáltuk meg az érintett szereplőknél:

- mióta van a vállalatnál önkéntesség, mióta van önkéntes stratégia;

- $\quad$ mi a célja a vállalati önkéntességnek;

- $\quad$ milyen vállalati önkéntes kezdeményezések a jellemzők;

- $\quad$ proaktív vagy reaktív a vállalat hozzáállása az önkéntességet tekintve;

- $\quad$ ki dönti el, hogy mit csináljanak önkéntes munka kapcsán;

- $\quad$ ki szervezi az önkéntességet;

- munkaidő keretben vagy azon kívül van-e mód az önkéntes munkára;

- egyéni és/vagy csoportos-e az önkéntesség;

- fizikai és/vagy szellemi-e az önkéntesség;

- $\quad$ az önkéntesség költségeit fedezi-e a vállalat;

- van-e fókuszterülete az önkéntességnek, milyen témák mentén szerveződnek a programok;

- $\quad$ meg van-e határozva a programok kedvezményezetti köre;

- munkatársak és kedvezményezettek felkészítik-e az önkéntes programok előtt;

- a vezetőség mennyire vesz részt az önkéntességben;

- a munkavállalók kapnak-e elismerést az önkéntes munkáért, illetve, hogy teljesítményértékelésüknél számít-e az önkéntesség;

- $\quad$ nyomon követi-e a vállalat az önkéntesség eredményeit és hatásait;

- mennyi a részt vevő munkatársak száma/év; 
- mennyi az önkéntességgel eltöltött munkaórák száma/év;

- az önkéntesség hatása a munkavállalók életére és a vállalat múködésére;

- milyen kommunikációs csatornákon kommunikálnak a vállatok az önkéntességről.

Igyekeztünk azt is feltárni, hogy voltak-e olyan nagyobb fordulópontok az egyes vállalatok önkéntes gyakorlatában, melyek esetleges szakaszhatárt jelenthettek-e az elmúlt 10 év során, külön kiemelve a koronavírus-járvány időszakát.

\section{A DM MAGYARORSZÁG KFT. ÖNKÉNTES GYAKORLATA AZ ELMÚLT TíZ ÉVBEN}

\section{Kezdetek (2013)}

A német eredetú vállalat ausztriai üzletlánca 2011-ben ünnepelte 35. jubileumát, amelyet az Önkéntesség Európai Évének ${ }^{3}$ alkalmából a Mehr vom Leben Tag $^{4}$ elnevezésú önkéntes kezdeményezéssel kötött össze. Ezt a vállalati önkéntes kezdeményezést 2013-ban vette át a magyar leányvállalat Egy nap másokért ${ }^{5}$ címmel, amely a mai napig nagy sikernek örvend. Az önkéntes program elindításának alapvető célja az volt, hogy a résztvevő munkatársak új, személyiségfejlesztő tapasztalatokat szerezzenek, mivel a vállalat nagy hangsúlyt fektet a munkatársak személyes fejlődésére. A program alapja, hogy a dm Magyarország munkavállalói minden évben egy munkanapot fordíthatnak önkéntes munkára a saját maguk által választott szervezetnél. Amennyiben a munkavállaló nem munkaidőben, hanem hétvégén megy önkéntesmunkát végezni, úgy cserébe egy szabadnapot biztosít számára a cég.

A magyar leányvállalat a programot 2013. február 1. és 2013. szeptember 1. között tesztjelleggel vezette be. A program szabályrendszerét egy munkacsoport dolgozta ki, amelyben a vállalat minden osztálya képviseltette magát. A munkacsoport munkáját egy a civilekkel való kapcsolattartásban jártas, külsős partner segítette, aki bevezette a munkacsoport tagjait a civilek világába, segítette őket a velük való kommunikáció kidolgozásában, és aki, egy kontaktlistát is biztosított az önkénteseket fogadó szervezetekhez. A listán lévő civil-nonprofit szervezeteket a dm megkereste, majd a beérkező információkat egy belső kommunikációs felületen rögzítették, hogy mely szervezetek, mikor, hány főt,

\footnotetext{
3 az Európai Parlament kezdeményezésére a 2011. évet az önkéntesség évének nyilvánították (https://www.europarl.europa.eu/at-your-service/hu/be-heard/eurobarometer/2011-european-year-ofvolunteering)

${ }^{4}$ https://www.dm.at/unternehmen/verantwortung/soziales-engagement/mehr-vom-leben-tag-219372

${ }^{5}$ https://www.dm.hu/vallalat/felelossegvallalas/egyuttegymasert/egy-nap-masokert-275046
} 
milyen önkéntes munkára várnak. A lista az olyan kollégák számára nyújtott segítséget, akik tanácstalanok voltak, hogy mely területen, milyen önkéntességet végezzenek. Az önkéntesek civil szervezethez, önkormányzati fenntartású intézményekhez, iskolákhoz, óvodákhoz, egyházi intézményekhez jelentkezhettek egyénileg vagy csoportosan. A szervezetek kiválasztásában egyetlen kikötés szerepelt: fegyveres vagy politikai irányultságú szervezetnél nem lehet önkéntességet vállalni. Arra azonban nem volt megkötés, hogy a befogadó szervezetek mennyire illeszkedjenek a vállalati stratégiához. Későbbi években ez, ha nem is elvárássá, de ajánlássá vált a vállalat önkéntes gyakorlatában. A munkavállalók feladata volt, hogy felvegyék a kapcsolatot az önkénteseket fogadó szervezetekkel - akár olyanokkal is, akik ebben az adatbázisban nem szerepeltek.

A cég a kommunikációs felületeken például belsős hírlevélben segédletet nyújtott a jelentkezőknek arról, hogy az önkéntes munka kapcsán mire figyeljenek oda: mi alapján válasszanak befogadó szervezetet; ne vágjanak bele olyasmibe, ami fizikailag vagy lelkileg túl megterhelő számukra; megfelelő öltözetet viseljenek a munka során. Emellett a vezetőknek egy érzékenyítő workshopot tartottak, de alapvetően a vezetőség nyitott volt, sőt ők maguk is vállaltak önkéntes munkát.

A dm kezdetben monitorozta, hogy az önkéntesek milyen szervezetekhez jelentkeznek. A cég nyomon követte, hogy hány munkavállaló, hová ment és mennyi időt töltött el önkéntes tevékenységgel. Az első évben rekordszámú volt az érdeklődés, több mint 500-an jelentkeztek, a munkavállalók 28,6 százaléka csatlakozott a kampányhoz, 3800 munkaórát töltöttek önkéntes tevékenységgel. Az önkéntes témák népszerüség szerinti sorrendben a következők voltak: állatvédelem, foglalkozás sérült gyerekekkel, természetvédelem, óvodai tevékenység, szociális tevékenység, anyaotthon, foglalkozás fogyatékos személyekkel.

\section{A keretek stabilizálódása (2014 - 2019)}

A vezetőség elvárása a kezdeti sikerek után az volt, hogy az első évet követően a munkacsopot elengedje a program kezét, és a munkavállalók önállóan szervezzék meg a saját önkéntességüket. A mai napig kulcsfontosságú, hogy a munkavállaló maga válasszon, ne az ölébe hulljon a lehetőség, hanem egy olyan ügy érdekében tegyen lépéseket, amely fontos neki és amely motiválja. Ezért is alakult úgy, hogy a vállalat központilag nem szervezett sohasem önkéntes eseményt, s nem adott pénzt vagy eszközöket a munka elvégzéséhez. 
2014-től tehát a munkacsoport aktivitása megszúnt, innentől a HR és a PR osztályok közösen terelgették a programot tovább, csendesebb, de állandó jellegű belső kommunikációval segítették, hirdetve, hogy az Egy nap másokért kampány továbbra is fut, és várják a lelkes jelentkezőket. A munkavállalókat rendszeres (havonta) e-mail hírlevelekkel bíztatták a részvételre. A levélben önkéntes lehetőségeket kínáltak, és amennyiben élménybeszámoló érkezett be a munkatársaktól, akkor azt is megosztották. Ettől függetlenül fontos volt a vezetők pozitív hozzáállása, hiszen a cégen belül jól látható az, mely területeken vonódnak be aktívabban a munkavállalók az önkéntes kedvezményezésbe.

A vállalat a külsős kommunikációs csatornákon a mai napig nem kommunikál a programról, mivel teljes mértékben a dolgozójuk döntésére hagyják, hogy szeretne-e részt venni az önkéntességben vagy sem. Emiatt a belső elhivatottság miatt mindig is kihívást jelentett és jelent a HR és PR osztályok számára az, hogy rábírják munkavállalóikat önkéntes munkájuk tapasztalatainak megosztására, mivel a dolgozók egyfajta kérkedésnek érzik a kérést, pedig ez lehetne a részükről akár példamutatás is. A cég az utánkövetés érdekében kezdetekben kérdőívet küldött ki, hogy visszajelzést kérjenek a résztvevőktől, ez azonban a fent említett okból nem volt eredményes. Éppen ezért a későbbiekben inkább közvetlenül keresték és keresik meg a résztvevő kollégákat, és élménybeszámolót kérnek tőlük.

2014-től a civil kontaktlistát igyekeznek frissen tartani (pl. egyéb dm-es pályázati programokra jelentkező civil szervezetek integrálása, a vállalat honlapján kint levő adatlapot kitöltve is jelentkezhettek szervezetek). Emellett bármely munkavállaló is szerkesztheti a szervezeti listát, újabb szervezeteket, önkéntes lehetőségeket adhat hozzá.

A statisztikák alapján 2014-ben a kezdeti lelkesedés csökkent, a következő évben már csak körülbelül 300 fő vett részt a programban, ami betudható volt annak, hogy a vezetőség próbálta elengedni a projekt szervezését. 2015-ben jelentkeztek a legkevesebben a programra, körülbelül 140-en vállaltak önkéntes munkát. Ennek egyik oka lehetett, hogy ebben az időben nem volt kiemelt felelőse ennek a területnek, továbbá a belső kommunikációban sem kapott nagy hangsúlyt a téma. 2016-ban azonban újból megemelkedett a részvételi arány, ismét 300 före emelkedett az önkéntességet vállalók száma, míg 2017-ben pedig 200-an jelentkeztek. Összességében 2014-2019 között évente átlagosan 250 munkavállaló végzett önkéntes munkát évi egy nap, 8 órában. Ezekben az években speciális projektekkel igyekeztek dinamizálni a dm Magyarországnál a vállalti önkéntességet: 
- általában a novemberi és decemberi időszakban, karácsony környékén az emberek érzékenyebben állnak hozzá a segítségnyújtási akciókhoz, így ezekben az időszakokban próbálnak a mai napig is plusz lendületet adni az önkéntesség vállalásának;

- 2018-ban a dm Magyarország fennállásának 25 éves évfordulóján pályázatot hirdetett, amelyre a dolgozók önkéntes projektekkel pályázhattak pénzbeli támogatásra, a projekt során 30-40 pályázat érkezett be, amelyből ötöt támogatott a cég;

- a dm Magyarország által kiírt pályázati projektek közül az elbírálás során előnyben részesültek azok a közösségi-jótékonysági projektek, amelyek megvalósítása során dmMagyarország munkatársaknak is lehetőségük volt részt venni.

\section{Pandémiás évek (2020 - 2021)}

A pandémiát megelőzően a fizikai önkéntesség volt jellemző a vállalati kezdeményezésekben. A koronavírus-járvány megjelenésével azonban a vállalat pro bono önkéntes kezdeményezésbe vágott bele, amelynek sikere elmaradt a fizikai önkéntes munkáétól. Eleinte nagy volt az érdeklődés, és voltak olyan munkavállalók, akik online együttmúködésbe kezdtek, és később offline folytatták azt. A kezdeti érdeklődés azonban gyorsan lankadt. Ennek egyik oka lehet, hogy az önkéntesek szeretnek kilépni a komfortzónájukból, kimenni otthonról, valami mást csinálni, mint ami megszokott. A pro bono önkéntesség azonban ezeket a lehetőségeket nem adta meg. Emellett a munkatársaknak időbe telt, amíg átálltak az online világban való otthoni munkavégzésre, adott esetben az otthon lévő kisgyerekek mellett. 2021ben az óvodák és az iskolák kinyitásával, valamint annak köszönhetően, hogy a vállalat integrálódott lelkileg, technikailag az online világba, így minden feltétel adott ahhoz, hogy mind a fizikai, mind a pro bono önkéntes programokat folytassák.

Mára jól láthatóvá vált az is, hogy a jelentkezők kevésbé használják a korábbi civil kontaktlistát. A mai működés szerint beérkeznek az önkéntes lehetőségek, a HR és PR osztály megnézi, helyileg hol találhatók, és regionálisan azoknak az osztályoknak, boltoknak ajánlják ki, akik a közelben vannak. Amennyiben egy szervezet fizikai munkához kér segítséget, úgy a megkeresést inkább olyan osztályoknak továbbítják, ahol több férfi dolgozik. A tapasztalat alapján tehát a munkavállalók inkább akkor érzik magukat megszólítva, ha személyre szólóan keresik meg őket az önkéntes lehetőséggel. A HR és PR osztály havi riportokat kap arról, hogy mennyi munkavállaló, hány órát tölt el önkéntes munkával. A kollégák a HR rendszerben, a munka-nyilvántartásban dokumentálják a CSR napokat is. A HR és PR osztály tehát nem látja 
a befogadó szervezeteket, a területi eloszlást, s igazolást sem kérnek az önkéntes munka

elvégzéséről. A programban való részvétel bizalmi alapon múködik. A különböző adatokra kizárólag a HR rendszerben található riportok alapján tudnak következtetni.

Az önkéntesek számára nincs központi elismerés, a teljesítmény-értékelésüknek nem része az önkéntesség. A cég filozófiája szerint alapvetően az egyén döntése az, hogy végez-e önkéntes munkát, mivel véleményük szerint az önkéntesség lényegét venné el az elismerés vagy a személyi értékelésbe való beépítése. A munkavállaló számára az a juttatás, hogy a vállalat fizeti azt a napot, amit nem mindennapi munkával, hanem önkéntes munkával tölt és ez által jót is tesz.

\section{AZ E.ON HUNGÁRIA CSOPORT ÖNKÉNTES GYAKORLATA AZ ELMÚLT TÍZ ÉVBEN}

\section{Keretek}

Egy cég alapvető célja az, hogy minél eredményesebb legyen a vállalkozása, viszont minél nagyobb egy vállalat, annál nagyobb szerepet kell vállalnia a társadalmi kezdeményezésekben - ez a szándék vezérli az E.ON Hungária Csoport társadalmi felelősségvállalását, így a vállalati önkéntességet is. Az E.ON szilárd meggyőződése, hogy a vállalat csak úgy lehet hosszú távon sikeres, ha gondolkodásában és tetteiben szem előtt tartja a társadalom hosszú távú érdekeit. Az E.ON Hungáriánál 2009-ben indultak el az önkéntes programok. A vállalat a kezdetektől fogva meghatározta a vállalati önkéntesség keretrendszerét, amelyen az évek során kisebb finomítások történtek, azonban alapjait tekintve a szabályrendszer változatlan maradt. 2009 óta van dedikált felelőse is a vállalati önkéntességnek, mert fontos szempont volt és lesz is a jövőben az önkéntesség koordinálása vállalati szinten, illetve az is, hogy legyen olyan felelős személy, aki támogatja az önkéntességet végző kollégákat a folyamatokban.

A munkavállalók évente 16 munkaórát fordíthatnak önkéntességre. Amennyiben hétvégén végzik a tevékenységet, úgy plusz szabadnapot kapnak. Az önkéntesek létszámát és az óraszámokat a HR rendszerben is adminisztrálják. A kimutatások szerint változó, hogy a dolgozók kihasználják-e a teljes 16 órás munkaidő keretet.

A vállalat az önkéntes programokat pénzügyileg is támogatja. A könyvelésben külön költségsor van az önkéntességre, ami alapvetően teljesen lefedi a korábbi éveket, inflációval, eszközköltségekkel együtt. Amennyiben a vállalti vezetés úgy látja, hogy az évi keret nem 
lenne elég, van lehetőség a pótlásra, de általában jól kijönnek az előre kalkulált pénzügyi keretből.

Az E.ON Hungáriánál az önkéntes programok céljai szerteágazóak: kultúra, tömegsport, oktatási és felújítási célú programjaik is vannak. Így a kedvezményezetti kör alapvetően nem határolható körül élesen, de a fókuszt a jövő generációjával és a fenntarthatósággal kapcsolatos projektek jelentik. A civil szervezeteket sem részesíti feltétlenül előnyben a cég: akár állami és önkormányzati intézményekhez, EGYMI-khez, iskolákhoz, óvodákhoz is lehet menni önkéntes munkavégzésre - tulajdonképpen mindenhova -, ahol szükség van a segítségre.

A vállalati önkéntes kezdeményezések több típusba tartoznak:

(1) központilag szervezett programok;

(2) a kollégák ad hoc jellegű, egyéni vagy csoportos kezdeményezéseinek megvalósítása; (

(3) „Tetterő” pályázati önkéntes program;

(4) edukációs és szakmai önkéntesség (E.ON „EnergiaKaland”, E.ON pro bono).

\section{Központilag szervezett programok}

A központilag szervezett önkéntes programokat az önkéntességért felelős munkatárs szervezi, több esetben külső szakmai partner bevonásával. Az elmúlt években az Önkéntes Központ Alapítvánnyal múködtek ebben együtt. A vállalaton belül a központilag szervezett programokra jelentkeznek a legtöbben, ugyanis ez a legkézenfekvőbb megoldás a kollégák számára. Ezeket a programokat kifejezetten úgy tervezik, hogy nagy létszámú események legyenek. Évente néhány központi eseményt szervez a cég, 2011 óta ilyen éves rendszeres program az „Adásnap”, országosan több helyszínnel.

\section{Ad hoc jellegü, egyéni vagy csoportos kezdeményezések}

Az egyéni és csoportos ad hoc jellegú megkeresések száma átlagosan 15-20 db, melyeket az önkéntességgel foglalkozó felelős kolléga az adott osztályon belül a vezetővel együtt hagy jóvá. Amennyiben nincs konkrét hely vagy programötlete az adott osztálynak, akkor az önkéntességért felelős személy segít a helyszínkeresésben, programötletben. Ahogy más vállalatoknál, így itt is előfordul, hogy bizonyos osztályok csapatépítő alkalomként végeznek önkéntes tevékenységet. 
Általában egy önkéntes csapatvezetőt jelölnek ki a programok alkalmával, ami megkönnyíti a szervezés folyamatát. A megvalósítást követően tőle kérnek beszámolót, képes dokumentációval együtt. A beszámolóba nemcsak a csapatvezető, hanem a csapat többi tagja is írhat. Ezeket a beszámolókat a belső kommunikációban felhasználják, hogy vállalaton belül bemutassák a megvalósult önkéntes programokat. A fizikai jellegű önkéntesség esetében ennél hosszabb utánkövetés nincs.

\section{„Tetterö" pályázati önkéntes program}

A „Tetterő” pályázati önkéntes programot évente kétszer hirdeti meg a cég, tavasszal és kora ősszel, amire átlagosan öt-öt pályázat érkezik. A pályázati programokat a munkatársak egyénileg adják le, de meg kell határozniuk, hogy hány fő szeretne részt venni a programban a cégen belül. $A$ „Tetterő” programoknál az Adományozási Bizottság választja ki a megfelelő projekteket. A pályázat során nagyobb összeget is el lehet nyerni, ezért részletes költségvetést kérnek a pályázóktól. Azokat a programokat preferálja a vállalat, amelyekben a kollégák kilépnek a saját ismeretségi körükből, s földrajzilag máshol találnak programot, mint ahol a mindennapjaikat élik. A pályázatok kiválasztásánál kizáró ok lehet az egyéni érdekeltség, illetve politikai érdekű szervezetekhez köthető programmal nem lehetséges pályázatot benyújtani. A pályázati alapot eredetileg azzal a céllal hozta létre az E.ON Hungária, hogy a vállalat mindennapjaiba bevigyék az önkéntesség témáját, és hogy minél több kolléga csatlakozzon. Ez elérte a célját, így mondhatni, mára „feleslegessé” vált ez a fajta önkéntes program. Viszont a koronavírus-járvány miatt jobbnak látta a vállalat meghagyni ezt a lehetőséget is, hogy plusz motivációként szolgáljon a kollégák számára.

\section{Edukációs és szakmai önkéntesség}

A vállalatnak vannak szakmai jellegű programjai is, ilyen pl. az E.ON EnergiaKaland, ami az egyik legnagyobb, szakértői önkéntességre lehetőséget adó projekt. Az EnergiaKaland lényege, hogy a munkatársak egy képzés elvégzése után, energetikai témákban (például energiabiztonság, energiapazarlás, fenntarthatóság) tartanak órákat - egyénileg vagy párosan - gyerekeknek, oktatási vagy egyéb, gyermekekkel foglalkozó intézményekben, eseményeken. Az óraadással kapcsolatban általában a kollégákat személyesen keresik meg a különböző, általában velük kapcsolatban álló intézmények, vagy kifejezetten a kolléga keresi fel ezeket az ismerős intézményeket: többnyire a saját gyermekeik vagy ismerőseik iskolái, óvodái és egyéb oktatási intézményei. Előfordul az is, hogy a központi felelőshöz érkezik óraadásra 
megkeresés, de az is, hogy a vállalat egy CSR programjába illesztik be a fenti programot és az önkénteseket.

A vállalat 2016 óta szervez pro bono napot, és erre a felhívást általában először civil szervezetek körében hirdetik meg. A jelentkező szervezetek esetében mindig sor kerül egy előszürésre. A munkatársi felhívás időbeliségére több példa is volt az évek során: volt, hogy a kollégák már az előszűrt projektekre jelentkezhettek; volt, hogy párhuzamosan történt a civil és munkatársi jelentkezés. 2021-ben a jelentkezett önkéntesekkel együtt választották ki a programban résztvevő civil szervezeteket, a következő témakörökre:

(1) folyamatszervezés, projektfejlesztés,

(2) HR, szervezetfejlesztés,

(3) kommunikáció és marketing,

(4) szervezeten belüli tudásfejlesztés.

A kiválasztás sarkalatos pontja a folyamatnak. A szakterületek alapvetően adottak, viszont sokféle pályázat érkezik be, amelyek kapcsán fontos megvizsgálni, hogy a projekt megvalósítható-e a felkínált szaktudásból, megvannak-e a megvalósítás technikai és személyi feltételei, társadalmilag hasznos- és hiteles-e a szervezet, elkötelezettek-e a munkatársak és a vezetők a pályázatban leírtak mellett. A programnak éves szinten kisebb létszámú az elérése a munkatársak körében, de alapvető cél az, hogy maximalizálják a létszámot körülbelül 20-30ban, ami még szervezési és technikai szempontból is könnyen átlátható. A program során öthat munkacsoport szokott felállni. A szervezetek és a munkatársak összepárosítását követően először egy diagnózis-alkalomra kerül sor. Ez egy félnapos program, ahol találkozik a két fél, átbeszélik a megjelölt célt és felkészülnek az ehhez szükséges feladatokra. Ezt követően hozzávetőlegesen két hét elteltével rendezik meg az E.ON a Pro Bono Maraton napot, ahol a munka nagyobb része történik. Az eredményekről a munkacsoportok prezentációt készítenek. Az események megvalósítását követően felmérést végez a cég a résztvevő civil szervezetek és a munkatársak körében is, hogy kiderüljön, sikerült-e megoldani a problémát, elégedettek-e az eredményekkel, megfelelőnek találták-e a közös munkát, valamint ekkor is visszajelzést adhatnak a résztvevők, hogy a szervezési és egyéb kérdésekben milyen finomhangolásokat vagy akár új elemeket érdemes megfontolni.

Az önkéntesek számának alakulása dinamikusan fejlődött az E.ON Hungáriánál az elmúlt tíz évben: 2009-ben még 160 fő; 2010-ben már 410 fő, 2016 és 2019 között átlagosan 500 fő, 
végzett önkéntes tevékenységet. A 2017-es kiemelkedő év volt, 700 főre emelkedett az önkéntesek száma. Az E.ON Hungária munkatársai az elmúlt években átlagosan 2500-3500 munkaórát fordítottak önkéntességre.

\section{Kommunikáció}

Az önkéntességgel kapcsolatos híreket a vállalat belső kommunikációs felületein teszik közzé, akár központilag szerveződő önkéntes programról van szó, akár a „Tetterő” program felhívásáról vagy a megvalósult projektek beszámolóiról. Év végén a vállalat összesítő videót készít az eredményekről, aminek alapján jól nyomon követhető, hogy a vállalat önkéntesei hányan voltak, hány munkaórát dolgoztak, infografikával, térképes illusztrációval is prezentálva, földrajzilag mekkora volt az önkéntesség hatóköre. Ezeket a videókat a vállalat a külső kommunikációban is használja és esetenként az E.ON a közösségi média felületeken is megjelenteti. Kiemelkedő programoknál vagy, ha a kedvezményezett ezt kifejezetten igényli, sajtóközleményt is kiad a cég. Ezen felül az E.ON Hungária Csoport minden évben riportálja az önkéntes programokhoz kapcsolódó adatait az anyavállalat felé: hány önkéntes kolléga, milyen programokon, mennyi munkaórában vett részt az adott évben. Ezek a számok az éves, nemzetközi cégcsoport szintű Fenntarthatósági Riport részét képezik.

\section{Elismerés, vezetői részvétel}

Az önkénteseket szimbolikus ajándékkal jutalmazza a vállalat: minden önkéntes munkát végző kolléga kisebb karácsonyi ajándékot kap, amit évek óta a pécsi Fogd A Kezem Alapítványtól ${ }^{6}$ szereznek be, hogy az erre szánt összeggel is egy társadalmilag fontos területen segítsenek. A vállalatnak van egy Önkéntes Díja is, amire a munkatársak egymást jelölhetik: ide olyan kollégák jelölését várják, akik a vállalat által meghirdetett önkéntes programokban vettek részt, vagy segítették a szervezést, és motiválták erre munkatársaikat is. A nyertes, évente egy fő, 50.000 Ft-os ajándékutalványt kap. A kiválasztás a cég belső kommunikációs oldalán történik, a munkatársak szavazatai alapján. A teljesítményértékelésben központilag nem elvárás az önkéntesség, előfordulhat azonban, hogy egyes vezetők ezt is figyelemmel követik. A vállalati önkéntesség elindulásakor a vezetőség is aktívan részt vett a programokban, személyes példájukkal is erősítve ezek megismertetését és elterjesztését. Az osztályszintű

\footnotetext{
${ }^{6}$ http://fogdakezemalapitvany.hu
} 
csapatépítő alkalmakra a vezetők is elmennek, illetve kiemelt programokon a legfelsőbb vezetés is részt vesz.

\section{Pandémiás évek (2020 - 2021)}

A koronavírus-járvány miatt 2020-ban és 2021-ben a személyes jelenlétet kívánó önkéntesség többször is átmenetileg szünetelt a cégnél. Így kiesett a tavaszi pályázati időszak is, ami például kifejezetten sűrű időszak szokott lenni, mivel a legtöbb program ekkor valósul meg. Amikor a szabályozások engedték a személyes programok megtartását, akkor is többnyire csak a központilag szervezett önkéntes események valósultak meg. Csoportos és egyéni ad hoc jellegú kérelmek ezekben az években alig voltak. 2020-ban a pandémia következtében a Pro Bono Maraton egy részét virtuális keretek között szervezte meg a cég, 2021-ben már sikerült személyesen megvalósítaniuk ezt a programot.

\section{AZ OTP BANK ÖNKÉNTES GYAKORLATA AZ ELMÚLT TíZ ÉVBEN}

\section{Keretek}

Az OTP Bank önkéntes kezdeményezéseinek középpontjában a segítségnyújtás, az értékteremtés és a közösségépítés áll. Az önkéntes tevékenységeken keresztül nem csak a támogatott szervezetekkel, helyi közösségekkel épít ki szorosabb kapcsolatot a bank, de célja, hogy erősítse a munkatársak egymás közötti kapcsolatát is, és lehetőséget nyújtson az önkéntes munka nyújtotta öröm átéléséhez. Az OTP Bank fontosnak tartja, hogy országszerte közvetlenül, helyben reagáljon az adott igényekre, és a helyi közösségek bevonásával valódi értéket teremtsen.

Az önkéntes tevékenység négy területre fókuszál:

(1) helyi közösségek segítése;

(2) öngondoskodás, oktatás, pénzügyi tudatosság fejlesztése;

(3) hátrányos helyzetűek támogatása;

(4) környezetvédelem.

Az önkéntes programok elbírálásánál előnyben vannak azok a projektek, melyek megfelelnek a vállalatcsoport fenntarthatósági alapelveinek és stratégiai céljainak, az etikai kódexben 
foglaltaknak, továbbá együttmúködő partnerük, a Humanitás Szociális Alapítvány7 célkitúzéseinek. A kedvezményezett szervezetek köre nem kötött, cél, hogy minél inkább a helyi igényekre reagáljanak a projektek.

A vállalatnál 2007-re tehetők az első önkéntes aktivitások, ekkor még jellemzően „ad hoc” jellegű kezdeményezésekként. Az első néhány évben a fizikai önkéntesség dominált, majd hamarosan megjelentek a pénzügyi edukációt középpontba helyező önkéntes programok is. Az önkéntes kezdeményezések folyamatosan fejlődtek az elmúlt években, és évről évre egyre több aktivitás épült be a vállalat önkéntes gyakorlatába:

(1) hagyományos önkéntes programok (pl. véradás, sütivásár);

(2) központi szervezésű vagy munkavállalói kezdeményezésre szerveződő adománygyűjtések (például tartós élelmiszergyújtés, „Mindenki Karácsonya” ajándékgyűjtés); (

(3) OTP Helyi Érték Önkéntes Pályázati Program;

(4) központi szervezésű önkéntes események;

(5) pro bono önkéntes aktivitások.

\section{Véradás}

Az OTP Banknál a véradásnak több mint 10 éves hagyománya van, évente átlagosan 900 kolléga 1600 alkalommal ad vért.

\section{Központi szervezésű vagy munkavállalói kezdeményezésre szerveződő adománygyűjtések}

\section{Munkavállalói kezdeményezések:}

A bank munkavállalói általában nagyobb, országos kezdeményezésekhez csatlakoznak önszerveződően, pl. Nem Luxus Táska ${ }^{8}$ és a Cipősdoboz ${ }^{9}$ akciók.

\section{Központi szervezésú gyújtések:}

Tartós élelmiszergyứjtés: A gyűjtésben 2012-től az OTP Fáy András Alapítvány Oktatási Központja és az Alapítvány két Mintaiskolája, 2015-től pedig az OTP Bank munkatársai is részt vesznek. 2017-től a Humanitás Szociális Alapítvány is csatlakozott a kezdeményezéshez. A koronavírus-járvány idején sem maradt el az adományozás, a munkatársak pénzadományából a járvány ideje alatt tartós élelmiszereket vásárolt és juttatott el rászorulóknak a cég.

\footnotetext{
${ }^{7}$ https://humanitasalapitvany.hu

8 http://nemluxustaska.hu

${ }^{9}$ http://ciposdoboz.hu
} 
Mindenki Karácsonya ajándékgyüjtés: A karácsonyi időszakban már hetedik éve szervezi meg a bank a Mindenki karácsonya ajándékgyújtést. A Nemzetközi Gyermekmentő Szolgálat segítségével 300 rászoruló gyermek számára juttatnak el adományokat minden évben. A Covid idején a dolgozók pénzadományaiból lepték meg a gyerekeket.

Gyereknap: A bank elhivatottan karolja fel azokat a kezdeményezéseket, amelyek beteg gyermekek gyógyulásához járulnak hozzá, illetve hátrányos helyzetű gyermekeknek segítenek. A közelmúltban a cég munkatársainak bevonásával a Dr. Bohóc Mosolyszolgálat Alapítványt segítette.

Az adománygyűjtő kampányok során a bank előre kommunikálja a gyűjtés célját, illetve utólag beszámol az eredményéről a munkatársaknak. Az adománygyűjtéseken évente kb. 1000 kolléga vállal szerepet.

\section{OTP Helyi Érték Pályázati Program - „Helyben vagyunk. Segítünk. Értéket teremtünk.”}

A programot 2010-ben indította a cég. A Helyi Érték Program keretében a munkatársak saját önkéntes csapatukkal pályázhatnak egy 150.000 Ft-os keretre, amelyből munkaidőn kívül önkéntes programot valósíthatnak meg. A pályázatokat szakmai zsűri bírálja el, ezt követi a megvalósítás, majd a beszámolási időszak. A bank kezdetben évente egyszer, később a munkatársak igényeinek növekedése miatt évente kétszer hirdeti meg a pályázati programot. A munkatársi részvételt 2017-től részletes pályázati kisokos segíti, ekkor kapta jelenlegi nevét is a program.

2019-től a Humanitás Szociális Alapítvány mentorként segíti az önkéntes csapatokat. Az alapítványt a munkatársak közvetlenül is megkereshetik, segítséget kérhetnek tőlük a kedvezményezettek felkutatásában, valamint a megvalósítás és az elszámolás során is. Az alapítvány emellett a zsűri munkájában is részt vesz.

A koronavírus-járvány előtt évente, pályázati időszakonként átlagosan 30 pályázat érkezett be, a programokra átlagosan 10-15 fős csapatok jelentkeztek, és gyakorlatilag a pályázati szempontoknak és a kitűzött céloknak megfelelő valamennyi önkéntes kezdeményezés szabad utat kapott a megvalósításhoz.

A pályázati program lezárását fényképes beszámoló követi, amely tartalmazza a program megvalósításának részleteit, a résztvevők számát, az önkéntességgel töltött időt, valamint a bevont szervezetek és kedvezményezettek számát és listáját. A beszámoló része a pénzügyi elszámolás is, számlákkal, bizonylatokkal szükséges bemutatni a 150.000 Ft-os támogatás 
felhasználását. Az önkéntesség munkavállalókra gyakorolt hatását kutatásokon, kérdőíveken keresztül vizsgálja a cég. Az erre vonatkozó legutolsó 2020-as kutatás válaszaiban megjelentek olyan önkénteseket motiváló tényezők, mint a valahova tartozás érzése, vagy a segítségnyújtás öröme.

A bank célja, hogy az OTP Csoport magyar leányvállalatit is bevonják a Helyi Érték Programba, valamint, hogy az önkéntes csoportok körében ösztönözzék a pro bono kezdeményezések megvalósítását.

\section{Központi szervezésű önkéntes programok}

A központi szervezésű önkéntességnek 5-6 éves hagyománya van a cégnél. Ezeket a fizikai önkéntességre alapuló lehetőségeket a vállalti CSR csoport organizálja a munkatársak számára. A hétvégékre szervezett önkéntes eseményekre a budapesti munkatársak mellé a régiós önkéntesek is könnyen bekapcsolódhatnak. Általában egy-két nagyobb központi aktivitás van évente, a résztvevők létszáma eléri a 80-100 főt is.

A programokhoz olyan civil-nonprofit szervezeteket választanak, akikkel már hosszabb távon együttmúködnek, az ő igényeikhez igazodva, de közösen alakítják ki a központi önkéntes programokat. Alapvető követelmény, hogy nagyobb számú önkéntes is aktívan részt tudjon venni, hasznosan hozzá tudjon járulni a projekt megvalósulásához.

\section{Pro bono}

A pro bono önkéntesség középpontjában a pénzügyi edukáció áll, melynek jelenleg elsődleges helyszíne - a pandémiás helyzetre tekintettel - az online tér. Ehhez kapcsolódóan elengedhetetlen, hogy a kedvezményezettek rendelkezzenek a szükséges digitális feltételekkel, amelyet az OTP Bank több éves számítógép és laptop adományozó tevékenysége támogat. A Http Alapítvány ${ }^{10}$, a Trenkwalder ${ }^{11}$ és a Microsoft mellett a bank is szerepet vállalt abban a programban, amely a munkából kiesők edukációját és mielőbbi munkába állását támogatja. A kollégák pro bono önkéntesség keretében, edukációs feladatokban és a résztvevők mentorálásban vesznek majd részt.

\footnotetext{
10 https://http-alapitvany.hu

${ }^{11}$ https://hu.trenkwalder.com
} 


\section{Kommunikáció, elismerés, vezetői részvétel}

Az önkéntes tevékenységek kommunikációja hangsúlyos megjelenést kap a bank kommunikációs felületein. A munkatársak felé cikkeken, illetve az irodaházak digitális felületein keresztül jutnak el az önkéntességgel kapcsolatos hírek. A bank közösségi média felületein, honlapján és a sajtóban is kommunikál a kiemelkedő önkéntes kezdeményezésekről és azok eredményeiről. A célcsoportok elérése érekében a bank egyre tudatosabb, előre tervezett, kampányszerű kommunikációt folytat, emellett az évente megjelenő fenntarthatósági jelentésben is kiemelt szerepet szánnak az önkéntességnek.

A bank 2016-ban vezette be a Felelősséggel Egymásért Díjat, amelyet az évente szervezett OTP Gálán adnak át. A díjjal olyan csapatokat ismernek el, amelyek a közösségépítésre és a társadalmi szerepvállalásra egyaránt nagy hangsúlyt helyeznek, illetve a helyi közösségek és a közvetlen környezet segítésére jöttek létre. Az önkéntes tevékenység elbírálása során a szakmai zsűri értékeli a bevonás mértékét, az elért hatást, a programok teljeskörűségét és komplexitását, valamint a hitelességet és a dokumentáltságot. Az első helyezett csapat támogatást nyer további önkéntes tevékenységeket megvalósításához.

A munkavállalók teljesítményértékelésnél az önkéntesség nem jelenik meg értékelési szempontként, mivel a bank nem szeretné, ha ez motiválná a munkavállalókat a segítségnyújtásra.

A pályázati programokon való részvétel a középvezetői és régióvezetői szinten is jellemző. Gyakori motivációként megjelenik a program csapatépítő jellege is. A központi önkéntes eseményeken szintén törekszenek arra, hogy vezetői példamutatással még inkább ösztönözzék a munkavállalókat a részvételre.

\section{Koronavírus - járvány hatása a vállalati önkéntes kezdeményezésekre}

2020-ban a járvány megjelenésekor épp folyamatban volt a Helyi Érték Önkéntes Pályázati Program tavaszi fordulója, de az év hátralevő részében a fizikai jelenléttel járó önkéntesség háttérbe szorult. A koronavírus-járvány alatt nem csökkent az önkéntes kedv a kollégák körében, bár számos korlátozás megnehezítette a korábbiakban megszokott programok megvalósítását, a munkatársak kreatív módon digitális és érintésmentes megoldások használatával hidalták át a nehézségeket. Ez az időszak számos tapasztalatot nyújtott, a kollégák a segítségnyújtás újabb (ezúttal digitális és érintésmentes) módszereit fedezték fel, melyeket a vírus után is be tudnak építeni önkéntes programjaikba. 2020-ban az átlagosnál 
kevesebb, megközelítőleg 250 fő végzett önkéntes munkát, a kedvezményezettek száma azonban nagyobb volt, feltehetően a digitális elérés miatt, az átlagos 2000 fős kedvezményezetti kör helyett kb. 2600 föt értek el. 2021 nyarán újra indultak a fizikai jelenlétet igénylö önkéntes események is, szeptemberben zajlott a központi önkéntes program, a nyáron meghirdetett pályázatok nyertesei pedig október végéig valósíthatták meg programjaikat.

\section{ZÁRSZÓ}

A vizsgált vállalatok jelentős piaci szerepe az elmúlt évtizedben egyre inkább megkövetelte, hogy a társadalmi felelősségvállalással, ennek részeként az önkéntességgel is szükséges foglalkozniuk. Ezt a cégek egyrészt a példamutatás miatt is fontosnak tartják, másrészt a társadalmi elvárások is ez irányba formálják a vállalati gyakorlatokat.

A három esettanulmányból kiderül, hogy a vizsgált cégeknél az elmúlt 10 évben alakult ki a vállalati önkéntesség gyakorlata, amihez stabil keretrendszerek is meghatározásra kerültek, valamint konkrét felelőst dedikáltak szervezeten belül az önkéntesség koordinálására, szervezésére (E.ON Hungária Zrt.-nél, OTP Bank Nyrt.-nél), illetve adott esetben csak inspirálásra (a dm Magyarország Kft.-nél). Az alulról jövő kezdeményezések mindhárom cégnél erősen jelen voltak és vannak, ezeket két cégnél (E.ON, OTP Bank) belsős pályázati rendszer is segíti, és utóbbi cégeknél a felülről jövő központi kezdeményezések is megtalálhatóak.

A fókuszterületek az OTP Bank esetén kifejezetten a CSR stratégiához kötődnek, míg a dm Magyarország és az E.ON esetében ez a terület egyéb vállalati stratégiákhoz kapcsolódik. A kedvezményezetti kört az önkéntességet tekintve mindhárom cég tágan értelmezi.

Az elemzésben szereplő cégek jellemzően proaktív hozzáállást tanúsítottak és tanúsítanak az önkéntesség során: a dm Magyarország és az E.ON esetében munkaidőben, az OTP Banknál pedig szabadidőben engedték, illetve engedik az önkéntes munkát, amelynél két esetben (E.ON, OTP Bank) a vállalat plusz anyagi erőforrásokat is biztosít.

Ezen vállalatok önkéntes tevékenységét inkább a csoportos fizikai munkák jellemzik, ugyanakkor üdítő kivétel az E.ON Pro Bono Maraton kezdeményezése. Az esettanulmányból az is jól kirajzolódott, hogy a koronavírus-járvány a fizikai önkéntességet hátráltatta, egyúttal lehetőséget adott a pro bono hazai piacon való térhódítására. Igaz, a nagyvállalatok még csak 
most ismerkednek ezzel az önkéntes tevékenységgel, jól látható viszont, hogy a jövőben még több lehetőség rejlik benne.

A vezetőség önkéntes programokban való részvétele mindhárom cégnél aktívnak mondható. Két vállalatnál (E.ON, OTP Bank) elismerésben részesítik év végén az önkéntességben részt vevő munkatársakat, ugyanakkor a dolgozók teljesítményértékelésének egyik cégnél sem része az önkéntes programokban való részvétel.

Az elemzés célkitúzése volt bemutatni azt is, nyomon követik-e a vállalatok a kezdeményezések eredményeit és hatásait. Az interjúk alapján elmondható, hogy a vállalatoknak nincsen egy kiterjedt mérési rendszere a programok eredményeinek és hatásainak mérésére. A leggyakoribb mutató, amit a vállalatok néznek az, hogy éves szinten, hány munkatárs, mennyi önkéntes munkaórát tölt el önkéntes munkavégzéssel. További visszacsatolást biztosít a cégek számára, hogy interjúkat készítenek az önkéntes munkatársakkal, vagy élménybeszámolókat kérnek tőlük a megvalósult programokról. Az interjúkból megállapítható, hogy a vállalatok célja - a jövőre nézve - a kezdeményezések sikeres fenntartása és fejlesztése. Továbbra is törekedni fognak a helyi igények feltárására, a hosszú távú együttmúködések kialakítására, a társadalom bevonásának elősegítésére. 